\title{
Iloprost suppresses connective tissue growth factor production in fibroblasts and in the skin of scleroderma patients
}

\author{
Richard Stratton, ${ }^{1}$ Xu Shiwen, ${ }^{1}$ Giorgia Martini, ${ }^{1}$ Alan Holmes, ${ }^{1}$ Andrew Leask, ${ }^{2}$ \\ Thomas Haberberger, ${ }^{2}$ George R. Martin, ${ }^{2}$ Carol M. Black, ${ }^{1}$ and David Abraham ${ }^{1}$ \\ ${ }^{1}$ Centre for Rheumatology, Royal Free and University College Medical School, University College London, \\ Royal Free Campus, London, United Kingdom \\ ${ }^{2}$ FibroGen Inc., San Francisco, California, USA \\ Address correspondence to: David Abraham, Centre for Rheumatology, Royal Free and University College Medical School, \\ Royal Free Campus, Rowland Hill Street, London NW3 2PF, United Kingdom. \\ Phone: 0044-207-794-0432; Fax: 0044-207-435-0143; E-mail: abraham@rfhsm.ac.uk.
}

Received for publication October 13, 2000, and accepted in revised form May 18, 2001.

Patients with scleroderma receiving Iloprost as a treatment for severe Raynaud's phenomenon report a reduction in skin tightness, suggesting that this drug inhibits skin fibrosis. Connective tissue growth factor (CTGF), a recently described profibrotic cytokine, acts downstream and in concert with TGF- $\beta$ to stimulate the fibrotic process and is involved in the fibrosis seen in scleroderma. Here we show that Iloprost, acting by elevation of cAMP, blocks the induction of CTGF and the increase in collagen synthesis in fibroblasts exposed to TGF- $\beta$. The potency of Iloprost with respect to suppression of CTGF far exceeds that of other prostanoid receptor agonists, suggesting that its effect is mediated by the prostacyclin receptor IP. By sampling dermal interstitial fluid using a suction blister device, we show that CTGF levels are greatly elevated in the dermis of scleroderma patients compared with healthy controls and that Iloprost infusion causes a marked decrease in dermal CTGF levels. These studies suggest that Iloprost could be reducing the level of a key profibrotic cytokine in scleroderma patients and that endogenous production of eicosanoids may limit the fibrotic response to TGF- $\beta$.

J. Clin. Invest. 108:241-250 (2001). DOI:10.1172/JCI200112020.

\section{Introduction}

Scleroderma is a connective tissue disease characterized by endothelial cell dysfunction, the development of occlusive vascular lesions, the presence of circulating autoantibodies, and the progressive scarring of skin and internal organs (1). The factors involved in the excessive scarring have been much studied, particularly factors related to cytokines and collagen synthesis (2). TGF- $\beta$ is found in fibrotic lesions and is believed to be a critical profibrotic mediator due to its known ability to stimulate collagen synthesis (3). More recent studies suggest that TGF- $\beta$ leads to the induction of another profibrotic cytokine, connective tissue growth factor (CTGF), which acts in concert with TGF- $\beta$ to drive the overproduction of collagen (4). CTGF is overexpressed in involved tissues in scleroderma where the levels of CTGF expression correlate with severity of the disease (5-8). Elevated production of CTGF would be expected to increase and sustain scarring and help to explain the progressive fibrosis seen in scleroderma.

The vascular injury associated with scleroderma causes a severe form of Raynaud's phenomenon in most patients and, in a significant minority, a form of pulmonary vascular disease causing pulmonary hypertension (9). Infusion of Iloprost, a synthetic prostacyclin analogue (10), has a beneficial effect in Raynaud's phenomenon and as a treatment for pulmonary hypertension in these patients
$(11,12)$. Scleroderma patients receiving Iloprost infusions frequently report an improvement in skin tightness consistent with an inhibitory effect on scar tissue formation by skin fibroblasts. In keeping with this observation it has been reported that prostanoids exert an inhibitory effect on the synthesis of collagen by fibroblasts in vitro $(13,14)$. In this study we have measured the effect of Iloprost on TGF- $\beta$-stimulated collagen and CTGF production by cultured human skin fibroblasts taken from healthy controls and from patients with scleroderma. In addition we have studied the effect of Iloprost infusion on the levels of CTGF in the dermis of patients with scleroderma.

\section{Methods}

Patients. Patients included in the study met the American Rheumatism Association diagnostic criteria for scleroderma and were classified according to internationally agreed upon guidelines $(15,16)$. Using these guidelines patients with skin sclerosis limited to hands, forearms, legs below the knee, and face were defined as having limited scleroderma. Those with more extensive skin disease spreading proximal to elbows or knees or involving the trunk were defined as having diffuse scleroderma. Scleroderma skin fibroblasts were derived from the involved skin of six patients with diffuse scleroderma. In addition skin blister fluid was derived from six patients with diffuse scleroderma and from six patients with limited scle- 
roderma. The scleroderma patients included had recentonset disease with less than 2 years since the development of skin involvement. The Royal Free Hospital ethical committee approval was obtained, and patients gave written informed consent to participate.

Fibroblast culture. Human skin fibroblast cultures were established by an explant technique using skin biopsies taken from the forearm of healthy volunteers and from the lesional skin of patients with diffuse scleroderma. Cells derived from six healthy individuals and the six diffuse scleroderma patients were used in each experiment at passage three to five. Fibroblasts were grown to confluence in DMEM, with $10 \%$ FCS with additional penicillin and streptomycin at $37^{\circ} \mathrm{C}$ in $5 \% \mathrm{CO}_{2}$. Confluent cultures were changed to serum-free DMEM with Lascorbic acid phosphate 24 hours before experiments. At the start of the assay fresh media containing $10 \mathrm{ng} / \mathrm{ml}$ TGF- $\beta 1$ and various concentrations of Iloprost were added to the cells. Media were removed after 24 hours of stimulation for assaying of CTGF and collagen.

Collection of skin blister fluid. Samples of dermal interstitial fluid were taken from the anterior forearm using a suction blister technique as described previously (17). Under a pressure of $275-325 \mathrm{mmHg}$ for 2-3 hours, small blisters were raised on the forearm and interstitial fluid sampled using an 18-gauge needle. This is a standard technique used in dermatological research for the collection of dermal interstitial fluid. Previous studies show that the sieve function of the capillary basement membrane is preserved during suction blister formation and that the fluid collected is representative of dermal interstitial fluid $(18,19)$.

Patients received intravenous Iloprost infusion for 6 hours per day for 5 consecutive days according to the following protocol: $0.5 \mathrm{ng} / \mathrm{kg} / \mathrm{min}$ for the first 20 minutes, $1 \mathrm{ng} / \mathrm{kg} / \mathrm{min}$ for the next 20 minutes, $1.5 \mathrm{ng} / \mathrm{kg} / \mathrm{min}$ for the next 5 hours and 20 minutes. Samples were taken before treatment on day 1 and during treatment on day 5. Heparin-Sepharose beads (17-0467-01; Amersham Pharmacia Biotech, Little Chalfont, United Kingdom) were used to affinity purify CTGF from the blister fluid. Five microliters of heparin-Sepharose beads were added per $100 \mu \mathrm{l}$ of blister fluid, and the samples rolled overnight at $4^{\circ} \mathrm{C}$. The beads were washed twice in PBS and then heated with $100 \mu \mathrm{l}$ of Western lysis buffer for 5 minutes at $95^{\circ} \mathrm{C}$, before the assay. A control sample containing recombinant human CTGF at $200 \mathrm{ng} / \mathrm{ml}$ was run in parallel with the samples.

ELISA of CTGF, collagen, prostaglandin $E_{2}$, and 6-keto prostaglandin $F_{1 \alpha}$. CTGF levels in the culture media were measured by ELISA using affinity-purified rabbit antihuman CTGF Ab and recombinant human CTGF as a standard. Collagen levels in media were measured by ELISA using affinity-purified polyclonal rabbit antihuman $\mathrm{N}$-terminal propeptide of type I procollagen (PINP). Prostaglandin $\mathrm{E}_{2}\left(\mathrm{PGE}_{2}\right)$, and 6-keto prostaglandin $\mathrm{F}_{1 \alpha}\left(6\right.$-keto $\mathrm{PGF}_{1 \alpha}$ ) were assayed by commercially available ELISA (R\&D Systems Inc., Minneapolis, Minnesota, USA).
Measurement of intracellular cAMP. Intracellular cAMP was measured using a commercially available enzyme immunoassay (Biotrak cAMP enzyme immunoassay RPN 225; Amersham Pharmacia Biotech).

Western blot analysis. For measurement of cell layer proteins, cells were grown to confluence in six-well plates, lysed with $200 \mu$ l of Western lysis buffer, and then heated for 5 minutes at $95^{\circ} \mathrm{C}$. For assay of type I collagen in the media, $200 \mu \mathrm{l}$ of saturated ammonium sulphate was added to each $1 \mathrm{ml}$ of media and rolled overnight at $4^{\circ} \mathrm{C}$, in order to precipitate the collagen. These samples were then centrifuged at $10,000 \mathrm{~g}$ for 40 minutes, and the protein pellet was resuspended in $100 \mu \mathrm{l}$ of Western lysis buffer and heated at $95^{\circ} \mathrm{C}$ for 5 minutes. Samples were loaded on 4-12\% Tris-glycine gels (Invitrogen, Paisley, United Kingdom) at $12 \mu \mathrm{l}$ per well and run with broadrange protein markers. Proteins were electrophoretically transferred to nitrocellulose (Hybond-C extra; Amersham Pharmacia Biotech), which was then left in PBS with 5\% milk protein and $0.05 \%$ Tween 20 for 2 hours, in order to block nonspecific binding. The nitrocellulose filters were stained with primary $\mathrm{Ab}$ for 1 hour using the following primary Ab's: rabbit polyclonal anti-human CTGF as above, rabbit anti-human collagen type I (759103R; BIODESIGN International, Kennebunk, Maine, USA), mouse monoclonal IgG anti-COX-1 (SC 7299; Santa Cruz Biotechnology Inc., Santa Cruz, California, USA) goat polyclonal IgG anti-COX-2 (SC-1746; Santa Cruz Biotechnology Inc.). The nitrocellulose transfers were washed three times and stained with biotinylated speciesspecific secondary $\mathrm{Ab}$ for 1 hour and again washed three times before staining with biotin substrate (VECTASTAIN; Vector Laboratories, Peterborough, United Kingdom), then chemiluminescent substrate (Amersham Pharmacia Biotech), and developed against photographic film (Hyperfilm ECL; Amersham Pharmacia Biotech).

Use of prostanoid receptor agonists. We used various prostanoid derivatives as agonists at each of the prostanoid receptors as follows: BW 245C, a hydantoin with $\mathrm{PGD}_{2}$-like activity that is a specific $\mathrm{DP}$ receptor agonist (20); 17-phenyl-trinor $\mathrm{PGE}_{2}$, a synthetic analogue of $\mathrm{PGE}_{2}$ that is both an EP1 and EP3 receptor agonist (21); Butaprost, a selective agonist for the EP2 receptor (22); Misoprostol, which has EP2, EP3, and EP4 receptor activity (23); Fluprostenol, an analogue of PGF $_{2 \alpha}$ with FP receptor activity (24); and U46619, which has $\mathrm{PGH}_{2} /$ thromboxane $\mathrm{A}_{2}$-like activity and is a TP receptor agonist (25) (all from Cayman Chemical, Ann Arbor, Michigan, USA). These agents were chosen because of their well-defined profile of prostanoid receptor activity and because of their suitability for use in tissue culture.

Isolation and analysis of total $R N A$ from the skin fibroblasts. Skin fibroblasts were grown to confluence on $100-\mathrm{mm}$ dishes in the presence of TGF- $\beta(10 \mathrm{ng} / \mathrm{ml})$ with or without Iloprost $(1 \mathrm{ng} / \mathrm{ml})$ added simultaneously. A dose of 1 $\mathrm{ng} / \mathrm{ml}$ of Iloprost was used because in preliminary doseresponse experiments we found consistent maximum suppression of CTGF protein levels with this concentration. After 8 hours, the cells were lysed in $1 \mathrm{ml}$ of TRIzol 
a

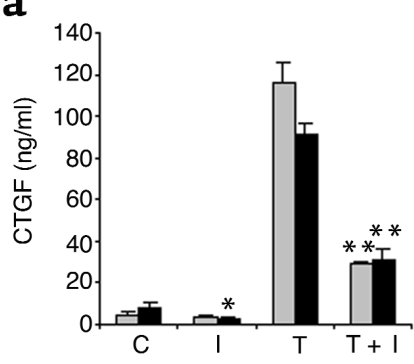

c

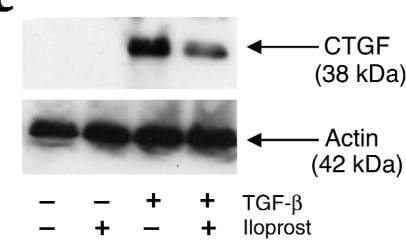

b

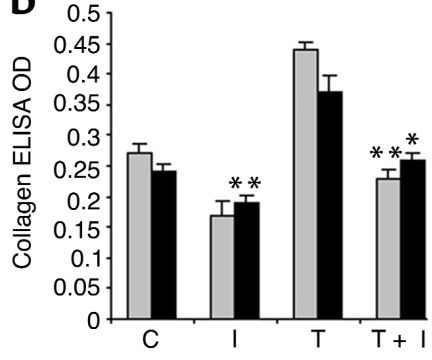

d

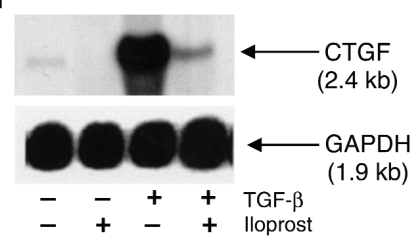

Figure 1

Normal (gray bars) and scleroderma (black bars) fibroblasts were grown to confluence on six-well plates. The experimental conditions were as follows: C, control with medium only; I, treated with $1 \mathrm{ng} / \mathrm{ml}$ lloprost; $\mathrm{T}$, treated with $10 \mathrm{ng} / \mathrm{ml} \mathrm{TGF-} \beta$; $\mathrm{T}+\mathrm{l}$, treated with $10 \mathrm{ng} / \mathrm{ml}$ TGF- $\beta$ plus $1 \mathrm{ng} / \mathrm{ml}$ lloprost added simultaneously. Media were removed after 24 hours for assay of (a) CTGF by ELISA, and (b) N-terminal propeptide of type I procollagen by ELISA. Values shown represent the means of six replicates of each experiment using cells derived from six patients with recent-onset diffuse scleroderma and from six healthy controls. ${ }^{*} P<0.05 ;{ }^{*} P<0.001$. (c) Normal human fibroblasts were grown to confluence and treated with $10 \mathrm{ng} / \mathrm{ml}$ TGF- $\beta$, with or without $1 \mathrm{ng} / \mathrm{ml}$ lloprost and then lysed after 24 hours. CTGF was assayed by Western blot analysis. (d) In other experiments normal human fibroblasts were grown to confluence and treated with $10 \mathrm{ng} / \mathrm{ml} \mathrm{TGF}-\beta$ with or without $1 \mathrm{ng} / \mathrm{ml}$ lloprost. After 8 hours, the cells were lysed, and RNA was extracted for Northern blot analysis. lysis buffer (Gibco 15596-018; Life Technologies Inc., Paisley, United Kingdom), and total RNA was extracted against $200 \mu \mathrm{l}$ chloroform. For Northern blot analysis 20 $\mu \mathrm{g}$ aliquots of RNA were denatured in formaldehyde, electrophoresed in $1 \%$ agarose gel, and then transferred to nitrocellulose filters. A cDNA probe specific for the human CTGF gene was radiolabeled using $\left[\alpha-{ }^{32} \mathrm{P}\right] \mathrm{dCTP}$ and the activity adjusted to $10^{6} \mathrm{cpm} / \mathrm{ml}$. The probe was hybridized against the nitrocellulose filter at $65^{\circ} \mathrm{C}$ for 16 hours in Church's buffer before autoradiography.

Adenoviral infection of cells. Normal human fibroblasts were grown to $50 \%$ confluence and infected with adenovirus-encoding CTGF as described previously (26). Cells were infected with 500 viral particles per cell. After a 2-hour infection period, media were removed and replaced by fresh DMEM, and subsequently the media were removed at various time points for assay of CTGF and type I collagen by Western blot analysis.

Cell-viability assay. The toxicity of Iloprost on human fibroblasts was tested using the tetrazolium salt WST1 (1644 807; Boehringer Mannheim Biochemicals Inc., Indianapolis, Indiana, USA).

Statistical methods. Assays were performed in triplicate. Replicates were performed six times for each experiment using cells derived from each of six patients. The mean values of each population were compared using Student's $t$ test.

\section{Results}

Effect of Iloprost on basal and TGF- $\beta$-stimulated CTGF synthesis. By using an ELISA of media, it was found under basal conditions that scleroderma fibroblasts secreted more CTGF than normal fibroblasts $(P<0.05$ : scleroderma cells, mean CTGF $=8.2 \mathrm{ng} / \mathrm{ml}, \mathrm{SEM}=2.3 \mathrm{ng} / \mathrm{ml}$; normal cells, mean CTGF $=4.2 \mathrm{ng} / \mathrm{ml}, \mathrm{SEM}=1.9 \mathrm{ng} / \mathrm{ml}$ ). The addition of Iloprost $(1 \mathrm{ng} / \mathrm{ml})$ reduced the amount of CTGF secreted by scleroderma fibroblasts $(P<0.05$ : mean CTGF $=2.7 \mathrm{ng} / \mathrm{ml} ; \mathrm{SEM}=0.6 \mathrm{ng} / \mathrm{ml})$, but not by normal fibroblasts $(P$ not significant: mean CTGF $=3.8$ $\mathrm{ng} / \mathrm{ml} ; \mathrm{SEM}=0.7)$. In normal fibroblasts the mean
CTGF secretion was increased to $116 \mathrm{ng} / \mathrm{ml}$ (SEM 9.9 $\mathrm{ng} / \mathrm{ml})$ after 24 hours of exposure to TGF- $\beta(10 \mathrm{ng} / \mathrm{ml})$. Similar results were obtained for scleroderma fibroblasts where the mean CTGF level was increased to $91 \mathrm{ng} / \mathrm{ml}$ (SEM $5.5 \mathrm{ng} / \mathrm{ml}$ ) after exposure to TGF- $\beta$. Coaddition of Iloprost $(1 \mathrm{ng} / \mathrm{ml})$ with the TGF- $\beta$ had a marked inhibitory effect on TGF- $\beta$-stimulated secretion of CTGF by both normal fibroblasts $(P<0.001$ : mean $\mathrm{CTGF}=29 \mathrm{ng} / \mathrm{ml} ; \mathrm{SEM}=1.5 \mathrm{ng} / \mathrm{ml})$ and scleroderma fibroblasts $(P<0.001$ : mean CTGF $=31 \mathrm{ng} / \mathrm{ml} ; \mathrm{SEM}=$ $5.0 \mathrm{ng} / \mathrm{ml}$ ) (Figure 1a).

Basal levels of type I collagen PINP were similar in media from scleroderma and normal cells. After exposure to Iloprost $(1 \mathrm{ng} / \mathrm{ml})$ there was a modest reduction in basal type I collagen production by normal ( $P$ not significant) and scleroderma cells $(P<0.001)$. Collagen synthesis increased after 24 hours' exposure to TGF- $\beta$ (10 $\mathrm{ng} / \mathrm{ml})$, and this increase was inhibited by coaddition of Iloprost $(1 \mathrm{ng} / \mathrm{ml})$ in both normal fibroblasts $(P<0.001)$ and scleroderma fibroblasts $(P<0.05)$ (Figure $1 b)$.

CTGF production in normal human fibroblasts was assessed by Western blot analysis, and showed a similar pattern of enhancement following exposure to TGF- $\beta$ and inhibition in the presence of Iloprost (Figure 1c).

To assess the effect of Iloprost on CTGF gene transcription we measured CTGF mRNA levels in normal fibroblasts treated with TGF- $\beta(10 \mathrm{ng} / \mathrm{ml})$ for 8 hours in the presence or absence of Iloprost $(1 \mathrm{ng} / \mathrm{ml})$. These studies showed that TGF- $\beta$ strongly induced CTGF mRNA levels in normal fibroblasts and that Iloprost inhibited the induction of CTGF mRNA by TGF- $\beta$ (Figure $1 \mathrm{~d}$ ).

Time course of the inbibitory effect of Iloprost. We measured the effect of adding Iloprost $(1 \mathrm{ng} / \mathrm{ml})$ to normal fibroblasts for varying periods and then washing it off, so as to determine the rapidity of action of Iloprost. Iloprost was used at $1 \mathrm{ng} / \mathrm{ml}$ because we had observed a consistent maximal suppression of CTGF with this concentration. Cells were then treated with TGF- $\beta$ (10 $\mathrm{ng} / \mathrm{ml}$ ) for 24 hours. Suppression of CTGF levels at 24 hours was seen following a 15-minute pretreatment 
a

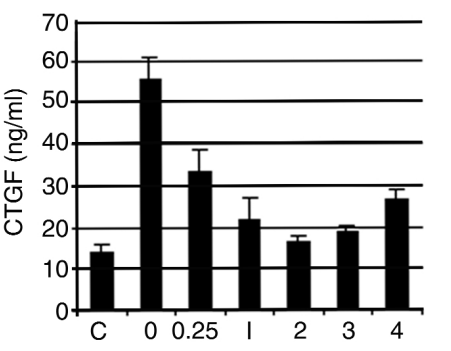

Duration of lloprost treatment (hours)

— TGF- $\beta 10 \mathrm{ng} / \mathrm{ml} \_$ b

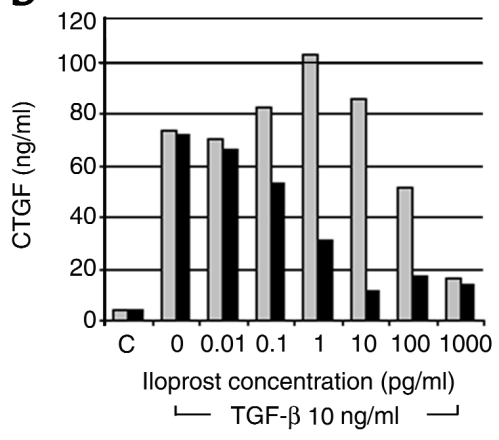

C

Timepoint

CTGF $2.4 \mathrm{~kb}$

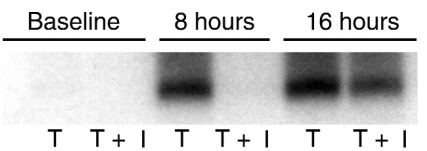

Figure 2

(a) lloprost $(1 \mathrm{ng} / \mathrm{ml})$ was added to normal fibroblasts and washed off at various time points. The cells were then treated for 24 hours with TGF- $\beta$ ( 10 $\mathrm{ng} / \mathrm{ml}$ ) and the media removed for CTGF assay by ELISA. C, untreated controls. (b) Normal fibroblasts grown to confluence were treated once (gray bars) at baseline with lloprost $(1 \mathrm{ng} / \mathrm{ml})$, or twice (black bars) (at baseline and after 12 hours) with lloprost $(1 \mathrm{ng} / \mathrm{ml})$, during 24 hours of treatment with TGF- $\beta(10 \mathrm{ng} / \mathrm{ml})$. C, untreated controls. (c) Normal fibroblasts were treated at baseline with TGF- $\beta(10 \mathrm{ng} / \mathrm{ml})$, with or without lloprost (1 $\mathrm{ng} / \mathrm{ml}$ ). Cells were lysed at baseline, 8 hours, and 16 hours, and RNA was extracted for the measurement of CTGF mRNA using Northern blot analysis. $T$, TGF- $\beta$-treated cells; $T+\mathrm{I}$, cells treated with TGF- $\beta$ plus lloprost added simultaneously. with Iloprost (Figure 2a), suggesting a rapidly evoked and relatively persistent cellular response to Iloprost.

We also assessed the persistence of Iloprost's action on blocking the induction of CTGF mRNA by TGF- $\beta$. Iloprost caused a marked suppression of TGF- $\beta$-stimulated CTGF mRNA expression at 8 hours, which was largely lost at 16 hours (Figure $2 \mathrm{~b}$ ). To determine whether the repeated addition of Iloprost would intensify the suppression of CTGF, we measured the effect of dual exposure to Iloprost $1 \mathrm{ng} / \mathrm{ml}$ at 0 and 12 hours during 24 hours of treatment with $10 \mathrm{ng} / \mathrm{ml}$ TGF- $\beta$. Repeat exposure to Iloprost reduced the minimum concentration of Iloprost required for the suppression of CTGF induction (Figure 2c).

Studies of the relative kinetics of induction and suppression of CTGF and collagen. We reasoned that if elevation of CTGF has an important role in the induction of collagen synthesis in fibroblasts exposed to TGF- $\beta$, then the rise in CTGF levels should temporally precede the rise in collagen levels after treatment with TGF- $\beta$. Also, if suppression of CTGF by Iloprost is responsible for the suppression of collagen synthesis, then CTGF levels should fall before any decrease in collagen levels. To test these possibilities we measured the kinetics of the induction of CTGF and type I collagen by TGF- $\beta$ using normal human fibroblasts. We used stimulation with TGF- $\beta$ at baseline to induce CTGF and collagen synthesis, and then added Iloprost $1 \mathrm{ng} / \mathrm{ml}$ at 12 hours to suppress the induction of CTGF and collagen at a time when it was partially evoked. We observed that induction of CTGF was rapid and fully developed at 12 hours, whereas the induction of type I collagen developed slowly over 72 hours (Figure 3, a and b). The addition of Iloprost at 12 hours lead to suppression of CTGF to near basal levels at 24 hours, whereas the levels of type I collagen continued to rise up to 36 hours and then began to decline (Figure 3 , $a$ and $b$ ).

The effect of infection of normal buman fibroblasts with adenovirus-encoding CTGF. We sought to demonstrate directly that elevation of CTGF leads to induction of collagen by infecting cells with an adenovirus-encoding CTGF and measuring the subsequent increase in the synthesis of CTGF and collagen. Normal human fibroblasts grown to $50 \%$ confluence were treated with adenovirus-encoding CTGF at 500 viral particles per cell for 2 hours and then a

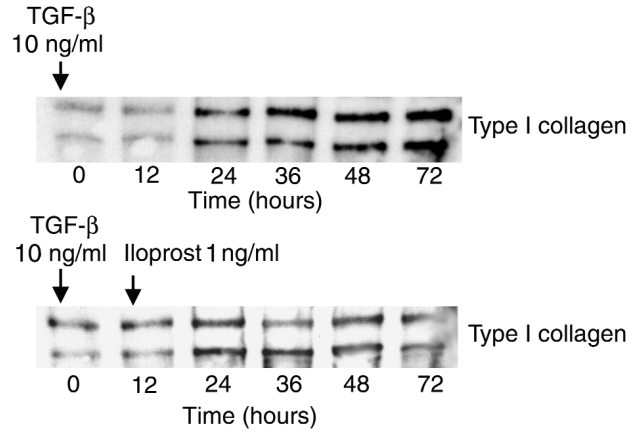

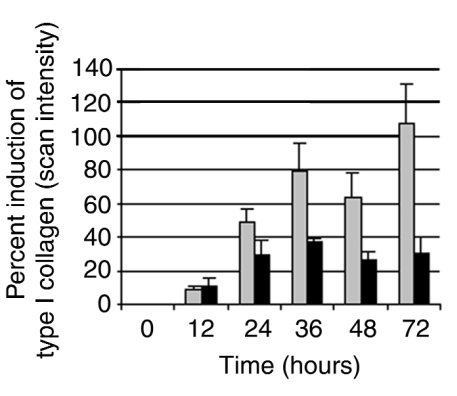

b

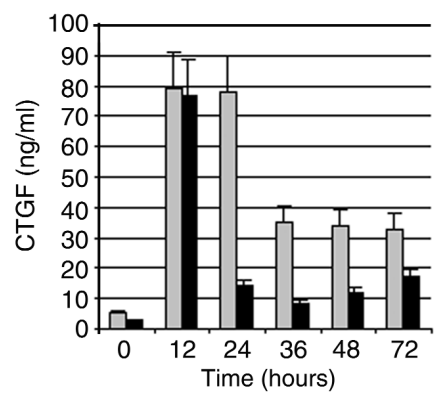

Figure 3

Normal human fibroblasts were grown to confluence in six-well plates and treated at baseline with TGF- $\beta$ (gray bars) (10 ng/ml). After 12 hours, lloprost $(1 \mathrm{ng} / \mathrm{ml})$ was added to the media of some of the cells (black bars). (a) Media were removed at various time points for type I collagen assay using Western blot analysis. (b) Additional assays were performed on the media to measure CTGF by ELISA. 


\section{Figure 4}

Normal human fibroblasts were grown to $50 \%$ confluence and infected with an adenovirus-encoding the CDNA for CTGF at 500 viral particles per cell. After 2 hours, the media were washed off and replaced with DMEM. (a) Subsequently, media were removed for assay of CTGF (gray bars) and type I collagen(black bars), by Western blot analysis. (b) The recombinant adenovirus encoding CDNA for human CTGF. LITR, left inverted terminal repeat; RITR, right inverted terminal repeat.

washed with fresh DMEM. Media were removed at various time points for measurement of CTGF and type I collagen by Western blot analysis (Figure 4). Under basal conditions low levels of type I collagen were detected in the media, but CTGF was not present. After infection with adenovirus-encoding CTGF, there was a rapid and marked increase in CTGF production apparent within 4 hours. Elevation of type I collagen above basal levels was not apparent until 24 hours after the infection, at which point there was fourfold increase in type I collagen. These results support the hypothesis that CTGF is involved in the induction of collagen synthesis and confirm the temporal relationship between CTGF synthesis and the induction of type I collagen synthesis.

The effect of Iloprost on intracellular cAMP in normal buman fibroblasts. In other cell types Iloprost has been shown to elevate cAMP by a specific prostacyclin (IP) receptor (27), and cAMP is known to block the induction of CTGF by TGF- $\beta$ (28). Therefore, we measured the effect of Iloprost on intracellular cAMP in normal human fibroblasts. The cells were treated with $1 \mathrm{ng} / \mathrm{ml}$ Iloprost at baseline and examined at various time points up to 24 hours. There was a marked elevation in intracellular cAMP after exposure to Iloprost apparent by 15 minutes and still present at 24 hours (Figure 5a). Pretreatment of the cells for 2 hours with $0.5 \mathrm{mM} 2^{\prime} 5^{\prime}$-dideoxyadenosine $\left(2^{\prime}, 5^{\prime}\right.$-DDA), an inhibitor of adenylate cyclase, attenuated the cAMP response to Iloprost at all time points up to 24 hours (Figure 5a). A dose-response curve of cAMP against Iloprost concentration was determined by treating normal fibroblasts with various concentrations of Iloprost for 30

Table 1

Suppression of TGF- $\beta$-stimulated CTGF production by specific prostanoid receptor agonists

\begin{tabular}{lccc}
\cline { 2 - 3 } Prostanoid receptor & Agonist & $\begin{array}{c}\text { EC 50 for CTGF } \\
\text { suppression }\end{array}$ & Reference \\
DP & BW 245C & $10 \mu \mathrm{M}$ & 20 \\
EP1 & 17-phenyl-trinor PGE & $>10 \mu \mathrm{M}$ & 21 \\
EP2 & Butaprost & $1 \mu \mathrm{M}$ & 22 \\
EP3 & Misoprostol & $1 \mu \mathrm{M}$ & 23 \\
EP4 & None available & & \\
FP & Fluprostenol & $>10 \mu \mathrm{M}$ & 24 \\
IP & Iloprost & $100 \mathrm{pM}$ & 10 \\
TP & U46619 & $>10 \mu \mathrm{M}$ & 25
\end{tabular}

Normal human fibroblasts were treated with $10 \mathrm{ng} / \mathrm{ml}$ TGF- $\beta$ in the presence of prostanoid receptor agonists added simultaneously. After 24 hours, the media were removed for CTGF assay by ELISA. a
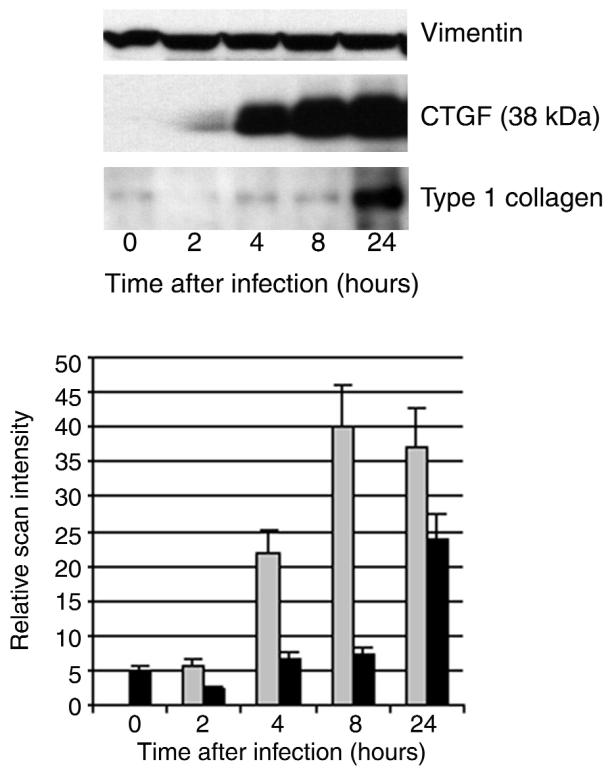

b

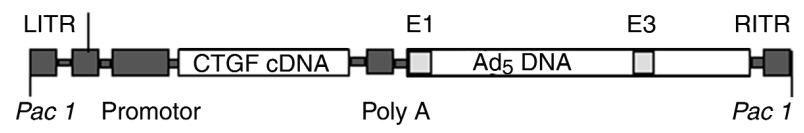

minutes before the measurement of cAMP by enzyme immunoassay (Figure 5b). Because we have used Iloprost in the presence of TGF- $\beta$ in many of the experiments described, we sought to determine whether Iloprost could elevate cAMP in the presence of TGF- $\beta$. Normal fibroblasts were treated with $10 \mathrm{ng} / \mathrm{ml} \mathrm{TGF}-\beta$ for 2 hours before treatment with various concentrations of Iloprost. After 30 minutes of Iloprost treatment, the cAMP levels were measured using the cAMP enzyme immunoassay. The elevation of cAMP by Iloprost was not affected by the presence of TGF- $\beta$ (Figure $5 b$ ).

In other experiments we sought to determine the effect of inhibition of adenylate cyclase on the suppression of CTGF by Iloprost. Normal human fibroblasts were treated with $2^{\prime}, 5^{\prime}$-DDA at a concentration of $0.5 \mathrm{mM}$ for 2 hours before exposure to TGF- $\beta$ (10 $\mathrm{ng} / \mathrm{ml})$ with or without Iloprost $(1 \mathrm{ng} / \mathrm{ml})$ for 24 hours. Attenuation of the cAMP response to Iloprost with $2^{\prime}, 5^{\prime}$-DDA abolished the suppressive effects of Iloprost on CTGF production, suggesting that such effects are due to elevation of cAMP (Figure $5 \mathrm{c}$ ). We also found that basal production of CTGF was increased in cells treated with $2^{\prime}, 5^{\prime}$-DDA, suggesting that under basal conditions CTGF may be directly repressed by endogenous levels of intracellular cAMP.

Comparison of the potency of specific prostanoid receptor agonists in suppression of TGF- $\beta$-stimulated CTGF production. Although Iloprost is principally an IP receptor agonist, it has also been reported to exhibit some EP1 receptor agonist activity (21). Moreover, it has been shown that the EP receptor agonist $\mathrm{PGE}_{2}$ has an 


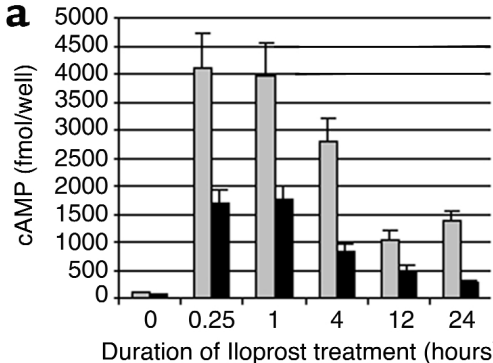

b

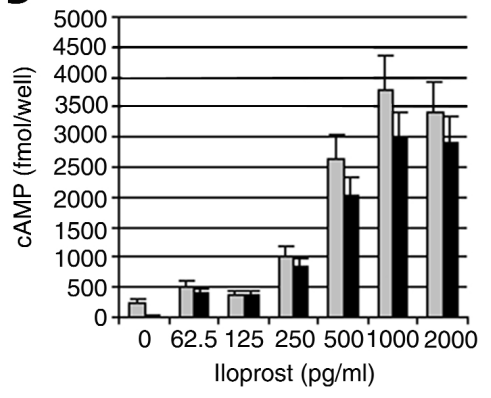

C

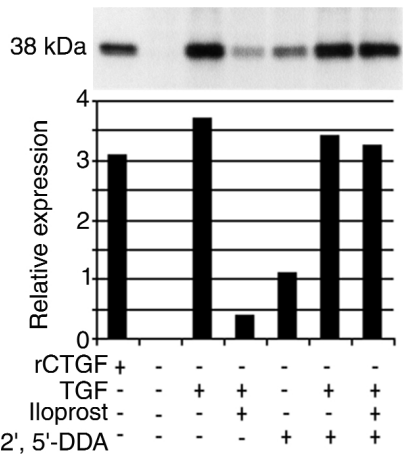

Figure 5

(a) Normal fibroblasts were grown to confluence on six-well plates and treated with lloprost ( 1 $\mathrm{ng} / \mathrm{ml}$ ) for various periods before lysis for cAMP measurement by enzyme immunoassay (gray bars). Other normal fibroblasts were treated with $2^{\prime}, 5^{\prime}$-DDA, an inhibitor of adenylate cyclase, for 2 hours before treatment with lloprost (black bars). (b) Normal fibroblasts were treated with lloprost at various concentrations for 30 minutes and then lysed for cAMP enzyme immunoassay (gray bars). Other normal fibroblasts were treated with TGF- $\beta$ ( $10 \mathrm{ng} / \mathrm{ml})$ for 2 hours before treatment with lloprost, in order to determine whether Iloprost can elevate CAMP in the presence of TGF- $\beta$ (black bars). (c) Normal fibroblasts were treated with TGF- $\beta(10 \mathrm{ng} / \mathrm{ml})$ with or without lloprost $(1 \mathrm{ng} / \mathrm{ml})$ for 24 hours and before lysis for Western blot analysis for CTGF. Other normal fibroblasts were pretreated with $2^{\prime}, 5^{\prime}$-DDA for 2 hours before such treatment. inhibitory effect on TGF- $\beta$-stimulated CTGF production (29). We sought to clarify the relative importance of the various prostanoid receptors in the suppression of CTGF by prostanoids by using specific agonists for each of the receptors (Table 1 ).

Normal human fibroblasts were treated with TGF- $\beta$ $(10 \mathrm{ng} / \mathrm{ml})$ in the presence of specific prostanoid receptor agonists at various concentrations for 24 hours, at which time the media were removed for CTGF assay by ELISA. Suppression of CTGF was greatest with Iloprost, and the sensitivity to Iloprost exceeded the sensitivity to other prostanoid receptor agonists by a factor greater than 1,000 (Table 1 ).

We also went on to compare the ability of the various prostanoid receptor agonists to elevate intracellular cAMP in normal human fibroblasts. Normal human fibroblasts were treated for 30 minutes with the various prostanoid receptor agonists and then lysed for assay of intracellular cAMP. The elevation of cAMP after exposure to Iloprost greatly exceeded the response to other prostanoid receptor agonists and correlated with the ability to suppress CTGF (Figure 6).

Comparison of prostanoid production by normal and scleroderma fibroblasts. Having shown that very low levels of Iloprost were able to elevate cAMP and suppress CTGF induction in human fibroblasts, we went on to determine whether endogenous prostanoids released by fibroblasts exert an inhibitory effect on CTGF induction. Our hypothesis was that prostanoids released by fibroblasts at sites of wounding act in an autocrineinhibitory fashion on the induction of CTGF and terminate the fibrotic response. Initially, we explored this by measuring the levels of $\mathrm{PGE}_{2}$ and prostacyclin (measured as the stable metabolite 6-keto $\mathrm{PGF}_{1 \alpha}$ ) in the media from normal human fibroblasts. We found large amounts of both $\mathrm{PGE}_{2}$ and 6-keto $\mathrm{PGF}_{1 \alpha}$ in the media from normal fibroblasts (Figure 7 , $a$ and b). Also, we treated the normal fibroblasts with TNF- $\alpha(10 \mathrm{ng} / \mathrm{ml})$, with or without TGF- $\beta(10 \mathrm{ng} / \mathrm{ml})$, in order to mimic the conditions at sites of wounding. Media were removed at 24 hours for measurement of $\mathrm{PGE}_{2}$ and 6-keto $\mathrm{PGF}_{1 \alpha}$ using ELISA. We found no induction of prostacyclin after treatment with TNF- $\alpha$ or TGF- $\beta$, but $\mathrm{PGE}_{2}$ production was found to increase slightly after treatment with TNF- $\alpha$, and this effect was enhanced in the presence of TGF- $\beta$ (Figure 7 , $a$ and $b$ ).

We wondered if fibroblast prostanoid production might be deficient in scleroderma cells, because this might account in part for the profibrotic phenotype seen in the disease. We therefore measured basal- and cytokineinduced production of $\mathrm{PGE}_{2}$ and 6-keto $\mathrm{PGF}_{1 \alpha}$ by scleroderma fibroblasts (Figure 7, $\mathrm{a}$ and $\mathrm{b}$ ). We were surprised to observe that prostanoid production was greatly elevated in scleroderma cells compared with normal cells, with both $\mathrm{PGE}_{2}$ and 6-keto $\mathrm{PGF}_{1} \alpha$ elevated under basal- and cytokine-treated conditions (Figure 7 , $a$ and $b$ ).

We compared levels of cyclooxygenase 1 and 2 in normal and scleroderma cells by Western blot analysis of cell layers after 24 hours of treatment with TGF- $\beta$ (10 $\mathrm{ng} / \mathrm{ml})$ or TNF- $\alpha(10 \mathrm{ng} / \mathrm{ml})$ or both. There was no difference in the levels of cyclooxygenase in the two cell types, and they showed similar patterns of basal expression and induction of cyclooxygenase (Figure 7c).

Addition of $5 \mu \mathrm{M}$ Indomethacin (a cyclooxygenase 1 and 2 inhibitor) was found to reduce $\mathrm{PGE}_{2}$ and prostacyclin production to about $25 \%$ of basal levels (data not shown). Normal human fibroblasts were exposed to $5 \mu \mathrm{M}$ Indomethacin for 2 hours before treatment with TGF- $\beta 10 \mathrm{ng} / \mathrm{ml}$. Media were removed at 24 hours and assayed by ELISA for CTGF. Suppression of endogenous prostanoid production by Indomethacin led to a minor enhancement of TGF- $\beta$-stimulated CTGF production $(P<$ $0.05)$, suggesting that endogenous prostanoid pro- 


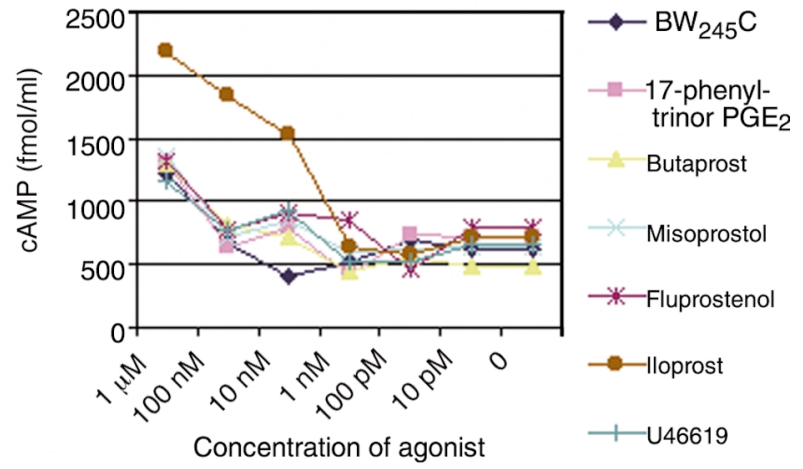

Figure 6

Normal fibroblasts were treated with various prostanoid receptor agonists for 30 minutes before lysis and measurement of cAMP by enzyme immunoassay.

duction by fibroblasts exerts a minor inhibitory effect on CTGF production (Figure 7d).

Effect of Iloprost infusion on CTGF expression in the dermis of scleroderma patients. Skin blister fluid was taken from the forearms of six healthy control individuals, from the forearm lesional skin of six patients with diffuse scleroderma before and after 5 days of Iloprost thera$\mathrm{py}$, and from the forearm lesional skin of six patients with limited scleroderma before and after Iloprost therapy. CTGF levels were elevated in fluids from scleroderma patients compared with controls $(P<0.01$; Figure 8). Skin blister fluid CTGF levels were reduced by 5 days of Iloprost therapy in diffuse scleroderma patients $(P<0.01)$ and decreased to a lesser extent in patients with limited scleroderma ( $P$ not significant).

Toxicity of Iloprost. Using the WST-1 viability assay, no significant toxicity was observed with the cells used here with Iloprost at concentrations up to $10 \mu \mathrm{g} / \mathrm{ml}$.

\section{Discussion}

CTGF is a member of the CCN family of cytokines, originally isolated from human umbilical vein endothelial cell-conditioned (HUVEC-conditioned) media (4). In human skin fibroblasts CTGF is induced specifically by TGF- $\beta$ at a transcriptional level, but not by PDGF, EGF, or bFGF (30). The CTGF promoter sequence has been shown to include a TGF- $\beta$ response element $(31,32)$, and TGF- $\beta$ and CTGF are overexpressed in a coordinated fashion in an in vivo model of wound repair, suggesting that TGF- $\beta$-stimulated CTGF expression is involved in the healing of wounds (30). In a mouse model of skin fibrosis the subcutaneous injection of TGF- $\beta$ produced only transient granulation tissue, and CTGF alone produced only a minor transient reaction (33). However, when CTGF and TGF- $\beta$ were given together, a more persistent fibrotic response was observed. Therefore it is likely that CTGF acts as a downstream effector of TGF- $\beta$ acting to enhance the production of scar tissue and that suppression of CTGF might prevent a progressive fibrotic response to stimulation by TGF- $\beta$. It has also been shown that inhibition of CTGF expression by antisense mRNA or by CTGF-binding Ab's prevents increased collagen synthesis in fibroblasts exposed to TGF- $\beta$, suggesting that CTGF induction is essential for the fibrotic response to TGF- $\beta$ (28). Furthermore, it has been shown that CTGF gene expression can be induced by exposure of fibroblasts to thrombin, suggesting that blood coagulation at sites of injury is involved in the enhancement of CTGF expression (34).

Collectively, conditions where the main pathological finding is that of fibrosis are very prevalent and include cirrhosis of the liver, congestive cardiac failure, diabetic nephropathy, and adhesion formation after surgical procedures. There is at present no effective therapy a

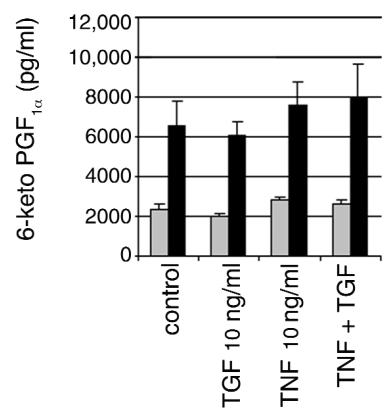

b

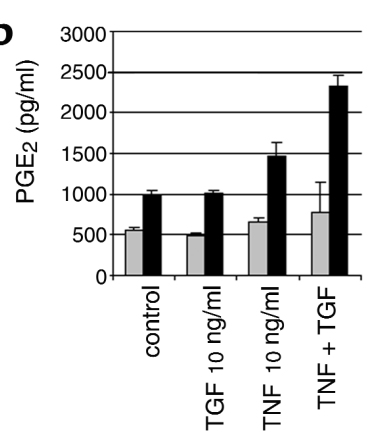

d

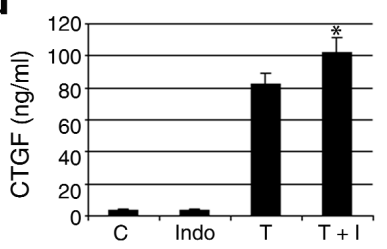

\section{Figure 7}

Normal (gray bars) and scleroderma (black bars) fibroblasts were treated with TNF- $\alpha$ $(10 \mathrm{ng} / \mathrm{ml})$, TGF- $\beta(10 \mathrm{ng} / \mathrm{ml})$, or both, for 24 hours, and the media removed for measurement of (a) 6-keto $\mathrm{PGF}_{1 \alpha}$, a stable metabolite of prostacyclin, and (b) $\mathrm{PGE}_{2}$ by ELISA. (c) Normal and scleroderma fibroblasts were treated with TNF- $\alpha(10 \mathrm{ng} / \mathrm{ml})$ or TGF- $\beta(10 \mathrm{ng} / \mathrm{ml})$, or both. After 24 hours, the cells were lysed for measurement of cyclooxygenase 1 and 2 by Western blot analysis. (d) To inhibit prostanoid production, normal fibroblasts were treated with Indomethacin $(5 \mu \mathrm{M})$, an inhibitor of cyclooxygenase 1 and 2, for 2 hours before treatment with TGF- $\beta(10 \mathrm{ng} / \mathrm{ml})$. Media were removed after 24 hours for assay of CTGF by ELISA. C, control cells treated with medium only; Indo, cells treated with $5 \mu \mathrm{M}$ Indomethacin; $\mathrm{T}$, cells treated with $10 \mathrm{ng} / \mathrm{ml}$ TGF- $\beta ; \mathrm{T}+\mathrm{I}$, cells treated with $10 \mathrm{ng} / \mathrm{ml} \mathrm{TGF-}$ $\beta$ plus $5 \mu \mathrm{M}$ Indomethacin. ${ }^{*} P<0.05$. 

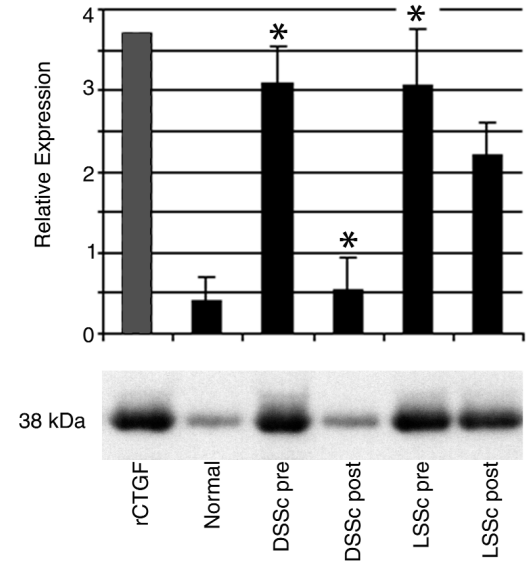

\section{Figure 8}

Forearm skin blister fluid was obtained from six healthy control subjects, from the lesional skin of six diffuse scleroderma patients before and after 5 days of lloprost therapy, and from the lesional skin of six limited scleroderma patients before and after 5 days of lloprost therapy. Blister fluid CTGF was measured by Western blot analysis. rCTGF, recombinant CTGF (200 ng/ml); Normal, healthy controls; DSSc pre, diffuse scleroderma patients before lloprost; DSSc post, diffuse scleroderma patients after Iloprost treatment; LSSc pre, limited scleroderma patients before Iloprost treatment; and LSSc post, limited scleroderma patients after lloprost treatment. ${ }^{*} P<0.01$.

shown to reverse or directly inhibit the scarring associated with these conditions. Scleroderma, although uncommon, is a good model for the study of fibrosis partly because biopsies can be performed on the fibrotic skin and lung lesions and the diseased cells can be studied in vitro. Using this approach in the present study we found that basal CTGF secretion was elevated in scleroderma cells compared with normal cells and that the addition of Iloprost suppressed basal CTGF secretion by scleroderma cells, reducing it to normal levels. We observed a marked increase in CTGF secretion after exposure of both normal and scleroderma fibroblasts to TGF- $\beta$, and this effect was inhibited by low levels of Iloprost. The full suppressive effect of Iloprost was preserved in dermal fibroblasts taken from the skin of patients with scleroderma. The suppressive effect of Iloprost on CTGF production was shown to be at the level of mRNA expression, suggesting that Iloprost might inhibit CTGF gene transcription or affect the stability of the CTGF mRNA. A 15-minute exposure to Iloprost before treatment with TGF- $\beta$ was sufficient to cause inhibition of CTGF induction, suggesting a rapidly evoked and relatively persistent cellular response to Iloprost. We also found that Iloprost suppressed the induction of CTGF mRNA 8 hours after treatment with TGF- $\beta$ and that this effect was lost by 16 hours. These observations have implications for the clinical use of Iloprost, suggesting that a brief exposure to the drug two or three times a day might be sufficient to maintain suppression of CTGF. In keeping with this we found that Iloprost treatment at baseline and at 12 hours during a 24-hour treatment with TGF- $\beta$ enhanced the suppression of CTGF and reduced the concentration of Iloprost required to suppress CTGF.
We have also studied the production of type I collagen by normal and scleroderma fibroblasts after exposure to TGF- $\beta$. We found no significant difference between normal and scleroderma cells with respect to basal and TGF$\beta$-stimulated type I collagen synthesis. Although it is often apparent that scleroderma fibroblasts produce excessive amounts of collagen, this is not a universal finding, and many cell lines derived from scleroderma skin biopsies express collagen levels within the normal range (35). We observed enhancement of type I collagen synthesis following exposure to TGF- $\beta$ and inhibition of this effect in the presence of Iloprost. One possible explanation for this effect is that CTGF expression is required for the enhancement of type I collagen production by TGF- $\beta$ and that the effect of Iloprost on type I collagen synthesis is due to its ability to suppress CTGF. To investigate this possibility further we have compared the kinetics of the CTGF and type I collagen response with TGF- $\beta$. We found that after treatment with TGF- $\beta$, the induction of CTGF was rapidly evoked, reaching a maximum at 12 hours, and that the type I collagen response developed more slowly, increasing over 72 hours. Also we found that when Iloprost was added 12 hours after TGF- $\beta$ stimulation, the CTGF response declined rapidly and was suppressed at the 24-hour time point, whereas the attenuation of the type I collagen response was slower to develop. These findings are consistent with the hypothesis that CTGF induction is involved in the type I collagen response to TGF- $\beta$ and that suppression of CTGF by Iloprost might be responsible for its effect on type I collagen synthesis.

To demonstrate directly that elevation of CTGF is involved in the induction of collagen synthesis we infected normal fibroblasts with an adenovirus-encoding CTGF. We observed elevation of CTGF synthesis within 4 hours of infection, followed at 24 hours by induction of type I collagen synthesis. These observations further support the hypothesis that CTGF is involved in the induction of collagen synthesis in fibroblasts.

It has been shown that Iloprost binds the IP receptor and that this receptor is $\mathrm{G}_{\mathrm{s}}$-protein linked (27). Also, IP receptor agonists activate adenylate cyclase and elevate intracellular cAMP in human cells such as platelets and astroglial cells $(36,37)$, and elevation of cAMP in fibroblasts suppresses CTGF expression (28). We therefore thought that the effect of Iloprost on CTGF expression might be due to elevation of intracellular cAMP. We found that exposure of human fibroblasts to Iloprost lead to a marked elevation of cAMP, with a time course and dose-response curve consistent with the suppressive effect of Iloprost on CTGF expression. The adenylate cyclase inhibitor 2',5'-DDA was used to attenuate the elevation of cAMP after exposure to Iloprost. We found that pretreatment of normal human fibroblasts with $2^{\prime}, 5^{\prime}$-DDA abolished the suppression of CTGF by Iloprost, and we conclude that the suppression of CTGF by Iloprost is due to elevation of intracellular cAMP. In addition, it was found that $2^{\prime}, 5^{\prime}$-DDA enhanced basal CTGF production in normal human fibroblasts, suggesting that under basal conditions CTGF production is suppressed by intracellular cAMP. 
Work from another group has shown that the prostanoid $\mathrm{PGE}_{2}$ has a suppressive effect on fibroblast CTGF production, consistent with our findings (29). Although Iloprost is mainly an IP receptor agonist, it also possesses EP1 receptor agonist activity (21). We therefore sought to determine the relative importance of the various prostanoid receptors in the suppression of CTGF by prostanoids. We have measured the effect of a number of specific prostanoid receptor agonists on TGF- $\beta$-stimulated CTGF production. We show that the sensitivity of CTGF induction to suppression by Iloprost exceeds the sensitivity to other prostanoids by several orders of magnitude.

We have also shown that the ability of prostanoid receptor agonists to elevate CAMP in normal human fibroblasts correlates with the ability to suppress CTGF, so that Iloprost has the greatest effect on cAMP and is effective at lower concentrations when compared with other prostanoid receptor agonists. Therefore we suggest that the natural agonist involved in suppression of CTGF production is prostacyclin and that the effects of prostanoids on CTGF production are mediated by an IP receptor.

Fibroblasts have been shown previously to release arachidonic acid metabolites, including $\mathrm{PGE}_{2}$ and prostacyclin $(38,39)$, and we confirmed this in the present study. The physiological roles of prostanoids in this context are not fully understood, but it has been suggested that prostanoids released by fibroblasts act in an autocrine inhibitory fashion to suppress fibroblast proliferation and collagen synthesis (40). At sites of wounding the production of prostanoids is enhanced, due in part to local production of TNF- $\alpha(41,42)$. Previous work from our departments has shown that TNF- $\alpha$ suppresses CTGF induction (43). We therefore propose a model where the coordinated overproduction of TNF- $\alpha$ and prostacyclin at sites of injury terminates the CTGF response to TGF- $\beta$, resulting in limited and healthy wound repair and preventing progression to the excessive scarring seen in fibrotic conditions. We have attempted to demonstrate this effect in vitro using the cyclooxygenase inhibitor Indomethacin to suppress endogenous fibroblast eicosanoid production. We found that pretreatment with Indomethacin lead to a modest enhancement of fibroblast CTGF production. The effect observed is not sufficient to imply an important role for fibroblast-produced eicosanoids in this system, although a role for eicosanoids in the suppression of CTGF at sites of injury is not excluded by these observations.

It is possible that the fibrotic phenotype of scleroderma cells results from a deficiency of the autocrine inhibitory effect of prostanoids on CTGF and collagen synthesis. We sought, therefore, to compare the production of $\mathrm{PGE}_{2}$ and prostacyclin by normal and scleroderma cells. Surprisingly, we found that prostanoid production by scleroderma cells greatly exceeded that by normal cells. This result is in contrast with previous findings in a different fibrosing condition, cryptogenic fibrosing alveolitis, where disease lung fibroblasts were shown to be deficient with respect to prostanoid production (44). This apparent discrepancy might be explained by a difference in the pathogenic mechanisms in the two diseases or by a differential response of lung and dermal fibroblasts to the process driving the fibrotic response. Possibly there is a defect in the proposed autocrine inhibitory mechanism in scleroderma cells downstream of prostanoid production that accounts for the elevation of basal CTGF and contributes to the profibrotic phenotype.

The effects of Iloprost on CTGF were observed with a concentration of Iloprost comparable to the plasma concentration obtained during therapeutic use of the drug (45). We went on to study the in vivo effect of Iloprost infusion on the expression of CTGF in the dermis of scleroderma patients. We took suction blister fluid from the affected skin of scleroderma patients before and after Iloprost infusion. The suction blister technique is a widely used method for obtaining dermal interstitial fluid, is reproducible, and has been used previously in studies of soluble factors in the dermis of scleroderma patients (17-19, 46). We found that CTGF levels were greatly elevated in samples from patients with both diffuse and limited scleroderma when compared with healthy controls. The elevation of CTGF in these samples is consistent with previous work showing increased levels of CTGF by immunohistochemistry in skin biopsy material from scleroderma patients (5). We believe that the elevated levels of CTGF are due to increased transcriptional activity of the CTGF gene and increased synthesis of CTGF, because we have shown previously by differential array analysis that CTGF mRNA levels are elevated in involved skin in scleroderma (7). The equivalence of CTGF concentration in samples from diffuse and limited groups is somewhat surprising because one might predict a more intense fibrotic process within the dermis of diffuse scleroderma patients who have more severe and extensive dermal fibrosis than patients with limited pattern of skin disease.

Iloprost infusion is used clinically to treat severe refractory Raynaud's phenomenon, in particular Raynaud's phenomenon associated with the connective tissue disease scleroderma, and appears safe and well tolerated in such patients (11). The results of the present study suggest that Iloprost infusion could have beneficial effects in addition to its properties as a vasodilator. We have shown that CTGF levels were decreased in skin blister fluid taken after 5 days of Iloprost therapy. Possibly, therefore, agonists at the IP receptor have an in vivo inhibitory effect on fibrosis. Our experiments with the time course of the effects of Iloprost suggest that a brief exposure to an IP receptor agonist, perhaps twice a day, may be sufficient to maintain an inhibitory effect on fibrosis. Other possible therapeutic approaches would include treatments designed to shift fibroblast prostanoid production from $\mathrm{PGE}_{2}$ to prostacyclin, because we believe this to be the endogenous prostanoid that mediates CTGF suppression. 


\section{Acknowledgments}

The authors would like to acknowledge the support of the Arthritis Research Campaign, The Raynaud's and Scleroderma Association, and Huw Beynon. Also we would like to thank Klaus Sondergaard and Bent Deleuran for the donation of the suction blister device and for their expertise with this technique.

1. Black, C.M., and Stephens, C.O. 1993. Scleroderma-systemic sclerosis. In Oxford textbook of rheumatology. P.J. Maddison, D.A. Isenberg, P. Woo, and D.N. Glass, editors. Oxford University Press. Oxford, United Kingdom. 771-789.

2. Jimenez, S.A., Hitraya, E., and Varga, J. 1996. Pathogenesis of scleroderma: collagen. Rheum. Dis. Clin. North Am. 22:647-674.

3. LeRoy, E.C., Smith, E.A., Kahaleh, B., Trojanowska, M., and Silver, R.M 1989. A strategy for determining the pathogenesis of systemic sclerosis. Arthritis Rheum. 32:819-825.

4. Bradham, D.M., Igarishi, A., Potter, R.L., and Grotendorst, G.R. 1991. Connective tissue growth factor: a cysteine rich mitogen secreted by human vascular endothelial cells is related to the SRC-induced immediate early gene product CEF-10. J. Cell Biol. 114:1285-1294.

5. Igarashi, A., et al. 1995. Significant correlation between connective tissue growth factor gene expression and skin sclerosis in tissue sections from patients with systemic sclerosis. J. Invest. Dermatol. 105:280-284.

6. Igarishi, A., et al. 1996. Connective tissue growth factor gene expression in tissue sections from localised scleroderma, keloid, and other fibrotic skin disorders. J. Invest. Dermatol. 106:729-733.

7. Shi-wen, X., et al. 2000. Autocrine overexpression of CTGF maintains fibrosis: RDA analysis of fibrosis genes in systemic sclerosis. Exp. Cell Res. 259:213-224.

8. Sato, S., et al. 2000. Serum levels of connective tissue growth factor are elevated in patients with systemic sclerosis: association with extent of skin sclerosis and severity of pulmonary fibrosis. J. Rheumatol. 27:149-154.

9. LeRoy, E.C. 1996. Systemic sclerosis: a vascular perspective. Rheum. Dis. Clin. North Am. 22:675-694

10. Skuballa, W., Raduchel, B., and Vorbruggen, H. 1985. Chemistry of stable prostacyclin analogues: synthesis of Iloprost. In Prostacyclin and its stable analogue Iloprost. R.G. Gryglewski and G. Stock, editors. Springer-Verlag. Berlin, Germany. 17-24.

11. McHugh, N.J., et al. 1988. Infusion of Iloprost, a prostacyclin analogue, for treatment of Raynaud's phenomenon in systemic sclerosis. Ann. Rheum. Dis. 47:43-47.

12. Higenbottam, T., Butt, A.Y., McMahon, A., Westerbeck, R., and Sharples, L. 1998. Long term intravenous prostaglandin (epoprostinol or Iloprost) for the treatment of severe pulmonary hypertension. Heart. 80:151-155.

13. Korn, J., Halushka, P., and Leroy, E. 1980. Mononuclear cell modulation of connective tissue function: suppression of fibroblast growth by stimulation of endogenous prostaglandin production. J. Clin. Invest. 65:543-554.

14. Goldstein, R., and Polger, P. 1982. The effect and interaction of bradykinin and prostaglandin on protein and collagen production by lung fibroblasts. J. Biol. Chem. 257:8630-8633.

15. 1980. Preliminary criteria for the classification of systemic sclerosis (scleroderma). Subcommittee for Scleroderma Criteria of the American Rheumatism Association Diagnostic and Therapeutic Criteria Committee. Arthritis Rheum. 23:581-590.

16. LeRoy, E.C., et al. 1988. Scleroderma: classification, subsets, and pathogenesis. J. Rheumatol. 15:202-205.

17. Kiistala, U. 1968. Suction blister device for separation of viable epidermis from dermis. J. Invest. Dermatol. 50:129-137.

18. Vermeer, B.J., Reman, F.C., and Van Gent, C.M. 1979. The determination of lipids and proteins in suction blister fluid. J. Invest. Dermatol. 73:303-305.

19. Rossing, N., and Worm, A.M. 1981. Exchange of macromolecules between plasma and skin interstitium. Clin. Physiol. 1:275-284.

20. Town, M., Casals-Stenzel, J., and Schillinger, E. 1983. Pharmacological and cardiovascular properties of a hydantoin derivative, BW 245C, with high affinity and selectivity for PGD2 receptors. Prostaglandins. 25:13-28.

21. Lawrence, R.A., Jones, R.L., and Wilson, N.H. 1992. Characterization of receptors involved in the direct and indirect actions of prostaglandins $\mathrm{E}$ and I on the guinea-pig ileum. Br. J. Pharmacol. 105:271-278.

22. Regan, J.W., et al. 1994. Cloning of a novel human prostaglandin receptor with characteristics of the pharmacologically defined EP2 subtype.
Mol. Pharmacol. 46:213-220.

23. Bunce, K.T., et al. 1991. GR63799X: a novel prostanoid with selectivity for EP3 receptors. Adv. Prostaglandin Thromboxane Leukot. Res. 21:379-382.

24. Abramovitz, M., et al. 1994. Cloning and expression of a cDNA for the human prostanoid FP receptor. J. Biol. Chem. 269:2632-2636.

25. Liel, N., Mais, D.E., and Halushka, P.V. 1981. Binding of a thromboxane A2/prostaglandin $\mathrm{H} 2$ agonist $\left[{ }^{3} \mathrm{H}\right] \mathrm{U} 46619$ to washed human platelets. Prostaglandins. 33:789-797.

26. Haberberger, T.C., Kupfer, K., and Murphy, J.E. 2000. Profiling of genes which are differentially expressed in mouse liver in response to adenoviral vectors and delivered genes. Gene Ther. 11:903-909.

27. Boie, Y., et al. 1994. Cloning and expression of a cDNA for the human prostanoid IP receptor. J. Biol. Chem. 269:12173-12178.

28. Duncan, M.R., et al. 1999. Connective tissue growth factor mediates transforming growth factor $\beta$-induced collagen synthesis: down-regulation by cAMP. FASEB J. 13:1774-1786.

29. Ricupero, D.A., Rishikof, D.C., Kuang, P.P., Poliks, C.F., and Goldstein, R.H. 1999. Regulation of connective tissue growth factor expression by prostaglandin E2. Am. J. Physiol. 277:1165-1171.

30. Igarishi, A., Okochi, H., Bradham, D.M., and Grotendorst, G.R. 1993. Regulation of connective tissue growth factor gene expression in human skin fibroblasts and during wound repair. Mol. Biol. Cell. 4:637-645.

31. Grotendorst, G.R., Okochi, H., and Hayashi, N. 1996. A novel transforming growth factor $\beta$ response element controls the expression of the connective tissue growth factor gene. Cell. Growth Differ. 7:469-480.

32. Holmes, A., et al. 2001. CTGF and smads, maintenance of scleroderma phenotype is independent of smad signaling. J. Biol. Chem. 276:10594-10601.

33. Mori, T., et al. 1999. Role and interaction of connective tissue growth factor and transforming growth factor-beta in persistent fibrosis. A mouse fibrosis model. J. Cell. Physiol. 181:153-159.

34. Sato, S., et al. 2000. Thrombin is a potent inducer of connective tissue growth factor production via proteolytic activation of protease activated receptor-1. J. Biol. Chem. 275:35584-35591.

35. Takeda, K., Hatamochi, A., Ueki, H., Nakata, M., and Oishi, Y. 1994 Decreased collagenase expression in cultured systemic sclerosis fibroblasts. J. Invest. Dermatol. 103:359-363.

36. Adie, E.J., Mullaney, I., McKenzie, F.R., and Milligan, G. 1992. Concurrent down-regulation of IP prostanoid receptors and the alpha-subunit of the stimulatory guanine-nucleotide-binding protein (Gs) during prolonged exposure of neuroblastoma $\mathrm{x}$ glioma cells to prostanoid agonists. Quantification and functional implications. Biochem. J. 285:529-536.

37. Ashby, B. 1988. Cyclic AMP turnover in response to prostaglandins in intact platelets: evidence for separate stimulatory and inhibitory prostaglandin receptors. Second Messengers Phosphoproteins. 12:45-57.

38. Torres, D., and Downie, E. 1983. Fibroblast prostaglandin E2 synthesis. J. Clin. Invest. 71:1240-1246

39. Shindo, N., Saito, T., and Murayama, K. 1988. Rapid quantification of 11 prostanoids by combined capillary column gas chromatography and negative ion chemical ionisation mass spectrometry: application to prostanoids released from normal human embryonic lung fibroblasts W138 in a culture medium. Biomed. Environ. Mass Spec. 15:25-32.

40. McAnulty, R.J., Hernandez-Rodriguez, N.A., Mutsaers, S.E., Coker, R.K., and Laurent, G.J. 1997. Indomethacin suppresses the anti-proliferative effects of transforming growth factor-beta isoforms on fibroblast cell cultures. Biochem. J. 321:639-643.

41. Nagaoka, T., Lundberg, C., Lebel, L., and Gerdin, B. 1984. Inflammatory reaction in an experimental model of open wounds in the rat. The role of polymorphonuclear leukocytes. Lab. Invest. 50:726-732.

42. Linz, D.N., Garcia, V.F., Arya, G., and Ziegler, M.M. 1994. Prostaglandin and tumor necrosis factor levels in early wound inflammatory fluid: effects of parenteral omega-3 and omega-6 fatty acid administration. $J$. Pediatr. Surg. 29:1065-1069.

43. Abraham, D.J., et al. 2000. Tumor necrosis factor alpha suppresses the induction of connective tissue growth factor by transforming growth factor-beta in normal and scleroderma fibroblasts. J. Biol. Chem. 275:15220-15225.

44. Wilborn, J., et al. 1995. Cultured lung fibroblast isolated from patients with idiopathic pulmonary fibrosis have a diminished capacity to synthesize prostaglandin $\mathrm{E}_{2}$ and to express cyclooxygenase. J. Clin. Invest. 95:1861-1868.

45. Krause, W., and Krais, T. 1986. Pharmacokinetics and pharmacodynamics of the prostacyclin analogue Iloprost in man. Eur. J. Clin. Pharmacol. 30:61-68.

46. Sondergaard, K., et al. 1997. Increased levels of type I and III collagen and hyaluran in scleroderma skin. Br. J. Dermatol. 136:47-53. 